\title{
Bioeconomy Investments: Market Considerations
}

\author{
Lauma ZIHARE ${ }^{*}$, Dagnija BLUMBERGA ${ }^{2}$ \\ ${ }^{1,2}$ Institute of Energy Systems and Environment, Riga Technical University, 12/1 Azenes iela, \\ Riga, LV1048, Latvia
}

\begin{abstract}
The introduction into the forestry sector of a bioeconomy has led to the search for new high value-added bio-products that can be produced using the woody biomass residue from timber harvesting. Any introduction of new bio-products must be justifiable from economic, socio-economic, and technological points of view. For successful commercialization, one important consideration is the market potential for such products. In this paper, a methodology for decision-making to evaluate three existing forest by-products for market potential in Latvia has been developed using the GE-McKinsey Nine-Box Matrix, considering market attractiveness and product competitive advantage. The methodological algorithm has been modified to include different factors such as process and product sustainability as well as competitive advantage. The analysis calculates the market attractiveness and competitive advantage of a specific product. As well, the application of this methodology makes a clear and presentable way of determining the viability of investing in new bio-products possible.
\end{abstract}

Keywords - Bioeconomy; commercialization; forest products; forest residues; GEMcKinsey Matrix; woody biomass

\section{INTRODUCTION}

The bioeconomy is experiencing worldwide growth and is playing an increasingly important role in the European Union [1], [2]. The existing fossil-based economy is being increasingly challenged by population numbers, climate change and a shortage of resources [3]. The bioeconomy counts on the availability and reliability of the supply of renewable resources for the production of high value-added products. Moreover, new bio-products are created in biorefineries, which results in both cleaner production and implements the cascade principle.

The cascade principle incorporates both the production of high value-added products and the use of residues to make those value-added products, thereby achieving little or no waste and reducing impact on the climate [3]. Bio-based products and bioenergy can have new and innovative functionality along with the potential to enter both new and existing markets [4].

Forests are an integral part of both the landscape and the overall economy. However, the economic benefits from timber production have been decreasing dramatically across Europe even though timber production creates major volumes of by-product or residue that can be used by the pulp industry and for energy production [5].

Forested lands cover about $52 \%$ of Latvia's total area [6]. Wood products are estimated to have excellent potential in Latvia if sustainability in the forestry sector can just be maintained; even more if sustainability can be enhanced. The problem is that most forestry biomass is combusted,

* Corresponding author.

E-mail address: lauma.zihare@rtu.lv 
that is, burned to produce energy, even though manufacturing forest products with greater added value is a strategic goal for the forest product industry [7].

Bioeconomy principles support the intention to create higher added value products from forest residue. But such products cannot be produced if they do not have proven economic viability. Effective feasibility studies are needed before attempting to create products from renewable resources on a commercial scale. Therefore, a clear methodology is needed as a first step to determine market opportunities for products that are supportive of the bioeconomy.

There are several studies done integrating the GE-McKinsey matrix as a tool for selecting appropriate markets [8]. For example, the Italian fashion industry [9] has used this methodology to determine the viability of certain markets. Kenya Airways has used it to determine route attractiveness and appropriate resource allocation [10]. All this research focusing on business strength and industry attractiveness, resulted in positive feedback. The aim of this paper is to develop a methodological algorithm for decision-making in the commercialization of bioproducts technology while taking into account environmental considerations. A case study has been developed for three existing products - lyocell (textile from wood), bio-oil and xylitol (a sweetener). After the results have been obtained, the capability of a product to enter a market as a primary product or as a value-added by-product of a biorefinery or not to enter at all should be determined.

\section{Methodology}

The methodology employed here (the GE-McKinsey Matrix) uses nine modules or boxes to denote aspects of the market for potential new bioproducts. The methodology has been developed and proven on three existing products Fig. 1.

First step: resource availability is the first step to promote a bioeconomy; the resource should be local and not dependent on import.

Second step: technology should be available on a commercial scale even if it is innovative technology, if innovative technology has not yet reached the commercial stage, it returns to the Research and Development (R\&D) stage.

Third step: decision making matrix, in this case the decision making matrix is the GE-McKinsey matrix that has been used for market assessments. Economic data and data about technology have been collected for calculations, as well as data about product competitiveness and data about the market. After obtaining the results, these data are placed in the matrix for decision making. A positive result from a calculation does not always show the actual situation; use of the matrix visualization is typically necessary. Information sources for the matrix consist of scientific publications, existing plant data and annual reports. Expert opinion, not including consumer surveys, can also be considered. Data analysis is carried out based on the collected data from information sources and shown in two dimensions - market attractiveness and product competitive advantage - on the GE-McKinsey Matrix [8]. The main data are collected from information sources such as scientific research papers or the subject company's data sources (excluding consumer surveys).

Fourth step is a matrix result visualization and recommendations on further assessment on new product production in the current location or country where local resources are available. 


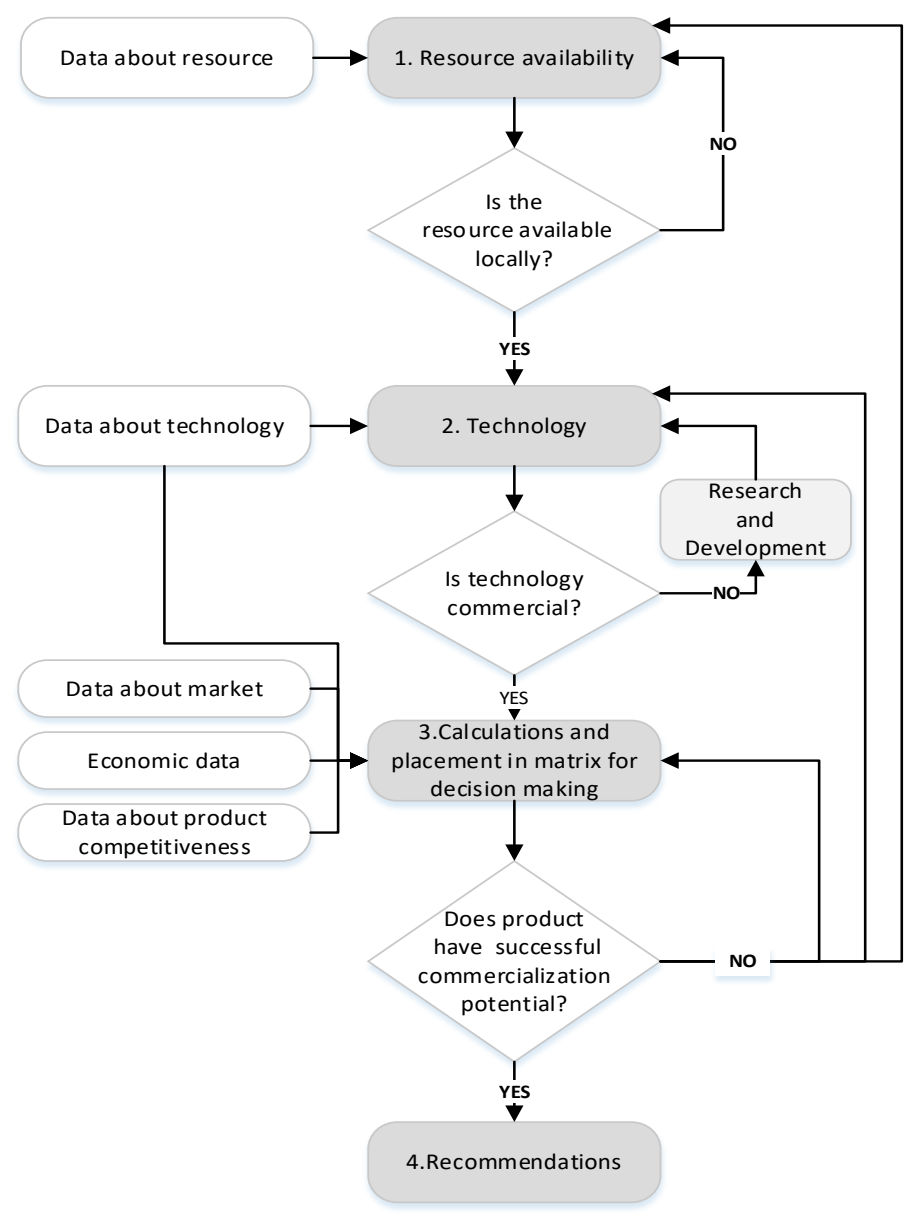

Fig. 1. Methodology algorithm.

\subsection{GE/McKinsey Matrix}

The methodology for the GE-McKinsey Matrix has been modified to include considerations and constraints such as environmental protection, required in the manufacturing process and product sustainability. Instead of the competitive position of the company, it shows the competitive attractiveness of a particular product. After obtaining results, it is possible to gain insight into market opportunities for the product.

A similar analysis can be made using the Boston Consulting Group matrix, which may be the best known such planning framework. However, the GE-McKinsey Matrix is newer and provides a more highly developed analysis with a broader range of factors. Basically the GE-McKinsey matrix is developed from the Boston Consulting Group matrix, as the latter was found not to be sufficiently flexible and, as well, had complexity issues [8]. The GE-McKinsey Matrix is widely used for product portfolio management and in the analysis of competitive scenarios [9]. 


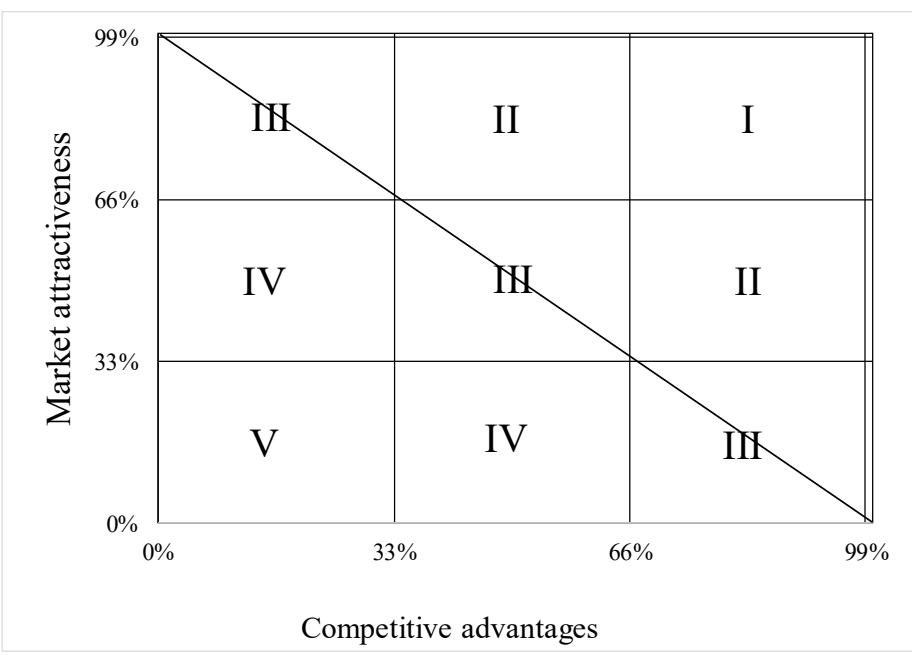

Fig. 2. "Market attractiveness - competitive advantages" matrix, or the GE-McKinsey Matrix [8], [9].

Fig. 2 shows products that fall above the diagonal line are high performers with commercialization potential; these are the products that a company needs to focus on. Products that fall below the line need to be further analysed and improved upon at least until they appear above that line. Otherwise they should be discounted or in some cases discarded. Products can also be evaluated based on the quadrant in which they are located. A product in the first quadrant is worth investing in with no further calculation or assessment and may be marked as a product leader. Products in the second quadrant have potential for growth, and it may be advisable for the company to invest in such products if improvements can be found and implemented. Products in the third quadrants are in passably attractive markets but before proceeding need to be evaluated further to see if there are opportunities for biorefining. Fourth quadrants represent weak markets; it is not advisable to invest in those products. Fifth quadrant products should be discarded [8], [11].

The advantage of this matrix is that it takes into account a wider range of factors than the Boston Group matrix and it is visually easier to understand. The GE-McKinsey Matrix has wider dimensions because it has nine fields, three times three grid. In comparison, the Boston Group matrix has only 4 fields, a two times two grid [8], [12].

However, the disadvantage of the GE-McKinsey Matrix is that compilation of the factor indicators can be difficult and the assessment and weight given to their importance are based on the opinion of a person or persons, albeit someone with demonstrated expertise in the subject field.

\subsubsection{Market attractiveness}

Market attractiveness replaces market growth as the measurement of industry attractiveness. An analysis of market attractiveness includes market size, market growth rate, market profitability, demand seasonality and cyclicality, price sensibility, differentiation of product, presence of equivalent competitors and their level of specialization, investment capacity and access to raw materials [13].

Market attractiveness may be calculated as follows: 


$$
M_{\mathrm{a}}=\frac{(z \cdot k)}{100}
$$

where

$M_{\mathrm{a}} \quad$ Market attractiveness total score;

$Z \quad$ Estimated rating score;

$$
k=\frac{100}{\left(f \cdot B_{\max }\right)}
$$

where

$k$ Coefficient;

$f \quad$ Number of factors;

$B_{\max } \quad$ Max rating score.

\subsubsection{Competitive Advantage}

An analysis of competitive advantage includes demand, market share, availability of resources, market price, product quality and environmental friendliness of the manufacturing process, for example, cleaner production, circular economy principles or greenhouse gas emission reduction in processes and resource consumption.

The evaluation of competitive strength is conducted using a five-point scale where 1 (one) represents a lower competitive advantage and 5 (five) a greater one. Each of the factors selected are weighted by importance and relevance.

Each factor is evaluated differently: higher demand for the product is weighted as five and lower demand is weighted as one. Market share is evaluated as follows: one represents 1-20\%, two represents $20-40 \%$, three represents $40-60 \%$, four represents $60-80 \%$ and five represents $80-100 \%$. For the availability of resources, five represents easily available and one indicates the resource is available but with difficulty. Pricing is from a manufacturer's perspective where one represents the lower selling price and five the higher price. For quality, five represents the highest quality and one the lowest acceptable quality. If little or no positive environmental impact results from the manufacturing process a one is assigned; whereas a five is assigned if the environmental impact is very positive. A circular economy, closed loop process, technologies and/or resources that result in decreased greenhouse gas emissions, ecological footprint etc. would be considered high positive impact and therefore would be given a five.

Competitive advantages or strengths can be evaluated for either a business unit or a product. In this case, the evaluation is done for a product and as competitors are selected, similar products based on resemblance in consumption and global market share will also be evaluated.

Market segmentation can be adapted to this assessment. If required, a particular product evaluated in one segment can be assessed in several segments to determine the resulting variations. The results of the evaluation in different segments are unlikely to be the same for any one particular product.

Different products from one particular resource, in this case woody biomass, cannot be compared, because the evaluation applies solely to the product evaluated. The means, for example, that a score of five for one product is not the same as a five for a second product.

The relative competitive advantage indicator is calculated by comparing a product with its strongest competitor and is expressed by the Eq. (3). 


$$
R=\left(\frac{B}{B_{\text {comp }}}-1\right) \cdot 100 \%
$$

where

$R \quad$ Relative indicator of product competitive advantages;

$B \quad$ New product score estimation;

$B_{\text {comp }}$ Strongest competitor score estimation [13].

\section{RESUltS AND DisCUSSION}

Lyocell is a man-made textile derived from wood cellulose. The leader in lyocell production is the Lenzing Group in Austria. It is widely acknowledged that lyocell has superior qualities to viscose, which is also derived from cellulose, and has price advantages compared to Modal (a similar textile from wood). Lyocell has a greater market share than all the cellulosic fibres produced by Lenzing. The highest demand for lyocell fibres is in the clothing segment, sportswear, after which comes the home textile segment. Lyocell fibre is produced in a closed cycle and is biodegradable [14], [15]. Lyocell can be manufactured using $\mathrm{N}$-methylmorpholine-N-oxide (NMMO) or Ionic liquid [16]. The tree species mostly used in lyocell production is eucalyptus [17].

Starting in 1989, bio-oil was used both in food and as a chemical additive in certain manufacturing processes. Since 2009, it has also been used in the production of electricity. From 2013, it has been used in biodiesel production. Today it replaces fossil fuels (mostly heavy fuel oil and natural gas) in energy production (electricity and heat) in both the residential and industrial sectors [18]. Mazut has not been used as a resource in cogeneration plants in Latvia since 2014. However, significant amounts of natural gas are being used, according to data from the Central Statistical Bureau of Latvia.

As the forestry industry is the main biomass and bioenergy supplier, there is considerable potential for bio-oil production in the European forestry sector [19]. Bio-oil commercialization would not represent a problem if the price of biomass were zero or close to zero. This not being the case, significant market demand is also required for the by-products of bio-oil in order to grow the market for bio-oil itself [20].

Global market demand for textile fibres in 2015 was $62.1 \%$; for synthetic fibres, $25.2 \%$; for cotton, $6.4 \%$; for cellulosic fibres, $5.1 \%$; for all other natural fibres and wool $1.2 \%$ [21]. Latvia's textile market is small and primarily focuses on export. Some $80 \%$ of output is redirected to European countries and to the CIS (Commonwealth of Independent States), including Russia [22]. According to forecasts, lyocell fibre in global markets will increase by $7.84 \%$ after CAGR (compound annual growth rate) in the period from 2016 to 2020 [23]. The required investments are EUR 150 million for a lyocell plant [21] and EUR 140 million for a pulp plant [24] with a production capacity of $67000 \mathrm{t} /$ year. The price of Lyocell is about $2.54 \mathrm{EUR} / \mathrm{kg}$ [25]. For profit calculations in Latvia's context [26] see Table 1.

The main competitors of bio-oil are mazut and natural gas [27]. There are no bio-oil plants in Latvia; however, there are some (bio-oil plants) in the EU including Fortum (Finland) and Empyro $B V$ (Netherlands) [20]. Bio-oil is carbon dioxide $\left(\mathrm{CO}_{2}\right)$ neutral and does not contain sulphur dioxide $\left(\mathrm{SO}_{2}\right)$. Moreover, bio-oil produces only half as much nitrogen oxide $\left(\mathrm{NO}_{\mathrm{x}}\right)$ as do fossil fuels [28]. 
TABLE 1. MAIN DATA USED IN THE ANALYSIS

\begin{tabular}{llllll}
\hline & $\begin{array}{l}\text { Global } \\
\text { market } \\
\text { demand }\end{array}$ & $\begin{array}{l}\text { Investments, } \\
\text { EUR million }\end{array}$ & $\begin{array}{l}\text { Capacity, } \\
\text { t/year }\end{array}$ & Price & $\begin{array}{l}\text { Profitability (calculated } \\
\mathbf{2 0 1 8}-\mathbf{2 0 3 0} \text { on 2030, } \\
\text { EUR/m }\end{array}$ \\
\hline Lyocell & $7.84 \%$ & 290 & 67000 & $2.54 \mathrm{EUR} / \mathrm{kg}$ & 65 \\
Bio-oil & $3 \%$ & 30 & 50000 & $9-15 \mathrm{EUR} / \mathrm{GJ}$ & 7 \\
Xylitol & $6 \%$ & 75 & 15000 & $6 \mathrm{EUR} / \mathrm{kg}$ & -20 \\
\hline
\end{tabular}

The capital investment for a bio-oil plant with a capacity of $50000 \mathrm{t} /$ year is 30 EUR million [29]. The price of bio-oil is about 9-15 EUR/GJ [30]. Profits from bio-oil in Latvia have been calculated to be very low and, in some cases, close to zero $\left(7 \mathrm{EUR} / \mathrm{m}^{3}\right)$ [26].

The main xylitol manufacturers are Danisco (DuPont), Futaste Pharmaceutical, Yucheng Luijan and Hangzhou Shouxing [31]. The forecasted growth rate is $6 \%$ both in quantity and in value [32]. The investment for a xylitol plant with a capacity of $15000 \mathrm{t} /$ year is 75 EUR million [33]. The price of xylitol is strongly dependent on the resources used both as feedstock and in production. The price of wood-derived xylitol is approximately $6 \mathrm{EUR} / \mathrm{kg}$ [34] while corn-derived xylitol fetches only $2.5 \mathrm{EUR} / \mathrm{kg}$ [26]. Profits from a xylitol plant located in Latvia are calculated to be negative [26].

After a market attractiveness evaluation, all three products showed better results in the international market but inferior results in Latvia's market. In Table 2, L stands for Lyocell, B for Bio-oil, and X for Xylitol and number one is for export market and number two is for local market (in this case Latvia is the local market). The evaluation is based on a five-point scale where one is very unattractive and five is very attractive. The external importance is indicated by its position on the scale: for example, low market growth is very unattractive and high market growth is very attractive, high price sensibility is very unattractive and low is very attractive.

TABLE 2. MARKET ATTRACTIVENESS EVALUATION RATINGS

\begin{tabular}{|c|c|c|c|c|c|c|c|c|}
\hline Factors & 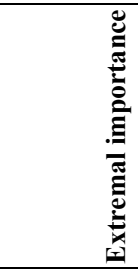 & 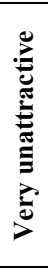 & 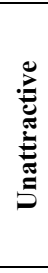 & Z & & 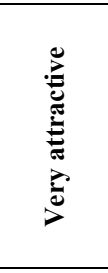 & 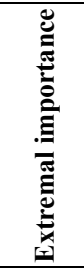 & Source \\
\hline \multicolumn{9}{|c|}{ Market factors } \\
\hline Market size & Little & & L2 & $\begin{array}{l}\text { B1; B2; } \\
\text { X1 }\end{array}$ & L1 & & Great & $\begin{array}{l}\text { [18], [19], } \\
{[21],[31],} \\
{[35],[36]}\end{array}$ \\
\hline $\begin{array}{l}\text { Market } \\
\text { growth }\end{array}$ & Low & & B2 & $\begin{array}{l}\text { B1; L2; } \\
\quad \text { X1 }\end{array}$ & & L1 & High & $\begin{array}{l}{[15],[31],} \\
{[32],[37]-} \\
{[41]}\end{array}$ \\
\hline $\begin{array}{l}\text { Demand } \\
\text { cyclicality }\end{array}$ & High & & & & $\mathrm{B} 2 ; \mathrm{X} 1$ & $\begin{array}{l}\text { L1; L2; } \\
\text { B1 }\end{array}$ & Low & $\begin{array}{l}{[18],[31],} \\
{[35]}\end{array}$ \\
\hline
\end{tabular}




\begin{tabular}{|c|c|c|c|c|c|c|c|c|}
\hline $\begin{array}{l}\text { Demand } \\
\text { seasonality }\end{array}$ & High & & & & $\begin{array}{l}\text { B1; B2; } \\
\text { X1 }\end{array}$ & L1; L2 & Low & \\
\hline $\begin{array}{l}\text { Price } \\
\text { sensitivity }\end{array}$ & High & $\begin{array}{l}\mathrm{L} 2 \\
\mathrm{~B} 2\end{array}$ & & $\begin{array}{l}\text { L1; B1; } \\
\text { X1 }\end{array}$ & & & Low & \\
\hline $\begin{array}{l}\text { Market } \\
\text { profitability }\end{array}$ & Low & $\mathrm{X} 1$ & $\begin{array}{l}\text { B1; } \\
\text { B2 }\end{array}$ & L2 & L1 & & High & [26] \\
\hline $\begin{array}{l}\text { Differentiation } \\
\text { of product }\end{array}$ & Low & & & & & $\begin{array}{l}\text { L1; L2; } \\
\text { B1; B2; } \\
\quad \text { X1 }\end{array}$ & High & $\begin{array}{l}{[18],[31],} \\
{[35],[42]}\end{array}$ \\
\hline \multicolumn{9}{|c|}{ Competitiveness factors } \\
\hline $\begin{array}{l}\text { Presence of } \\
\text { equal } \\
\text { competitors }\end{array}$ & Many & $\mathrm{X} 1$ & & L1; B1 & L2 & $\mathrm{B} 2$ & Few & \\
\hline $\begin{array}{l}\text { Competitor } \\
\text { level of } \\
\text { specialization }\end{array}$ & Low & & & L2 & $\begin{array}{l}\mathrm{L} 1 ; \mathrm{B} 2 ; \\
\quad \mathrm{X} 1\end{array}$ & B1 & High & $\begin{array}{l}\text { [19], [20], } \\
{[30],[31],} \\
{[35],[43]}\end{array}$ \\
\hline \multicolumn{9}{|l|}{ Entry barriers } \\
\hline $\begin{array}{l}\text { Investment } \\
\text { capacity }\end{array}$ & Great & $\begin{array}{l}\text { L1; } \\
\text { L2 }\end{array}$ & $\mathrm{X} 1$ & & B1; B2 & & Little & $\begin{array}{l}\text { [23], [24], } \\
{[29],[33]}\end{array}$ \\
\hline $\begin{array}{l}\text { Access to raw } \\
\text { materials }\end{array}$ & Difficult & & & & & $\begin{array}{l}\mathrm{L} 1 ; \mathrm{L} 2 ; \\
\mathrm{B} 1 ; \mathrm{B} 2 ; \\
\quad \mathrm{X} 1\end{array}$ & Easy & {$[44]-[46]$} \\
\hline
\end{tabular}

Note: L1 - lyocell for export market; L2 - lyocell for local market; B1 - bio-oil for export market; B2 - bio-oil for local market; X1 - xylitol for export market; "very unattractive" is 1 and "very attractive" is 5.

Table 3 shows the total weighted score for products and their competitors. In all textile segments the strongest competitor is considered to be the synthetic. In the natural segment (the segment that includes only natural fibres) wool is the strongest competitor in the local market and linen the strongest in the export market. The strongest competitor for bio-oil is natural gas. For xylitol, it is sorbitol. 
Table 3. Competitive Advantage Evaluation Weights and Ratings

\begin{tabular}{|c|c|c|c|c|c|c|c|c|c|c|c|c|}
\hline \multirow{2}{*}{$\begin{array}{l}\text { Factors } \\
\text { Market }\end{array}$} & \multicolumn{2}{|c|}{ Demand } & \multicolumn{2}{|c|}{ Market share } & \multicolumn{2}{|c|}{$\begin{array}{l}\text { Availability } \\
\text { of } \\
\text { resources }\end{array}$} & \multicolumn{2}{|c|}{ Price } & \multicolumn{2}{|c|}{ Quality } & \multicolumn{2}{|c|}{$\begin{array}{l}\text { Environmental } \\
\text { actions in } \\
\text { manufacturing } \\
\text { processes }\end{array}$} \\
\hline & $\begin{array}{l}\bar{J} \\
0 \\
\end{array}$ & 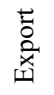 & $\begin{array}{l}\overline{\mathscr{J}} \\
0 \\
\ddots\end{array}$ & 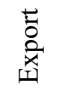 & $\begin{array}{l}\overline{0} \\
0 \\
\end{array}$ & 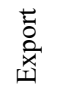 & $\begin{array}{l}\overline{\mathscr{J}} \\
\stackrel{\Xi}{1}\end{array}$ & 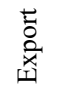 & $\begin{array}{l}\overline{0} \\
0 \\
\end{array}$ & 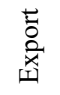 & $\begin{array}{l}\bar{\Xi} \\
0 \\
\end{array}$ & 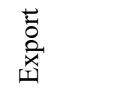 \\
\hline Weight & 0.2 & & 0.15 & & 0.2 & & 0.2 & & 0.15 & & 0.1 & \\
\hline $\begin{array}{l}\text { Lyocell (all textile } \\
\text { segment) }\end{array}$ & 3 & 5 & 2 & 2 & 5 & 4 & 4 & 4 & 5 & 5 & 5 & 5 \\
\hline 1. Cotton & 4 & 2 & 3 & 3 & 1 & 3 & 2 & 3 & 4 & 4 & 2 & 2 \\
\hline 2. Synthetic (PP) & 5 & 4 & 5 & 4 & 2 & 3 & 2 & 2 & 3 & 3 & 1 & 1 \\
\hline 3. Wool & 1 & 1 & 1 & 1 & 2 & 3 & 5 & 5 & 4 & 4 & 1 & 2 \\
\hline $\begin{array}{l}\text { Lyocell (natural textile } \\
\text { segment) }\end{array}$ & 4 & 5 & 3 & 3 & 5 & 5 & 4 & 4 & 5 & 5 & 5 & 5 \\
\hline 1. Cotton & 3 & 3 & 4 & 5 & 2 & 2 & 2 & 2 & 3 & 3 & 1 & 1 \\
\hline 2. Linen & 2 & 2 & 2 & 2 & 3 & 3 & 4 & 4 & 3 & 3 & 3 & 3 \\
\hline 3. Wool & 1 & 1 & 1 & 1 & 4 & 3 & 5 & 5 & 4 & 4 & 2 & 2 \\
\hline Bio oil & 3 & 4 & 3 & 3 & 5 & 5 & 5 & 5 & 3 & 3 & 5 & 5 \\
\hline 1. Natural gas & 5 & 5 & 5 & 4 & 1 & 2 & 2 & 2 & 4 & 4 & 2 & 2 \\
\hline 2. Heavy fuel oil & - & 1 & - & 2 & - & 1 & - & 1 & - & 2 & - & 1 \\
\hline Xylitol & - & 5 & - & 4 & - & 5 & - & 3 & - & 5 & - & 4 \\
\hline 1. Sorbitol & - & 3 & - & 5 & - & 3 & - & 5 & - & 3 & - & 4 \\
\hline 2. Maltitol & - & 2 & - & 3 & - & 3 & - & 4 & - & 4 & - & 4 \\
\hline
\end{tabular}

In most situations at least 3 competitors have been evaluated. But in the case of bio-oil there are only 1 or 2 as shown in Table 4, because the evaluation is based on the direct use of bio-oil excluding the use of products that can be further obtained or derived from bio-oil. Competitors are chosen based on the product, not the resource. Sorbitol and maltitol have been selected as competitors for xylitol, where both are low-intensity sweeteners, the same as xylitol.

TABle 4. TOtAl Weighted SCORES FOR COMPetitive AdVANTAgeS

\begin{tabular}{lll}
\hline & \multicolumn{2}{c}{ Total weighted score } \\
& Local market & Export market \\
\hline Lyocell (all textile segment) & 3.95 & 4.15 \\
1. Cotton & 2.65 & 2.85 \\
2. Synthetic (PP) & 3.10 & 2.95 \\
3. Wool & 2.45 & 2.75 \\
\hline
\end{tabular}




\begin{tabular}{|c|c|c|}
\hline Lyocell (natural segment) & 4.30 & 4.30 \\
\hline 1. Cotton & 2.55 & 2.70 \\
\hline 2. Linen & 2.85 & 2.85 \\
\hline 3. Wool & 2.95 & 2.75 \\
\hline Bio oil & 4.00 & 4.20 \\
\hline 1. Natural gas & 3.15 & 3.20 \\
\hline 2. Heavy fuel oil & - & 1.30 \\
\hline Xylitol & - & 4.35 \\
\hline 1. Sorbitol & - & 3.80 \\
\hline 2. Maltitol & - & 3.25 \\
\hline
\end{tabular}

Results for lyocell are the following - lyocell local market attractiveness is $65 \%$; its competitive advantage $27 \%$; its export market attractiveness is $80 \%$ and competitive advantage $41 \%$. Lyocell shows better results than the competition in the natural segment - lyocell local market attractiveness in the natural segment is $65 \%$ and $46 \%$ for competitive advantage; lyocell natural segment export market attractiveness is $80 \%$ and competitive advantage $51 \%$.

The results for bio-oil show that its competitive advantage is low: $27 \%$ for the local market and $31 \%$ for the international market. In the local market, its attractiveness reaches $71 \%$ and in the international market $76 \%$.

As for xylitol, the strongest competitor is calculated to be sorbitol. The relative competitive advantages are only $14 \%$ in international markets; while among low intensity sweeteners, its market attractiveness is $62 \%$.

The competitive advantage for all products shows low to average results. However, the most promising is lyocell. The GE-McKinsey matrix shows that while lyocell in the international market has a good position in both segments, it has a better position only in the natural segment in the local market. It is also very advisable to make supplementary assessments before considering the commercialization of this product.

Bio-oil's market attractiveness helps it to achieve a relatively high result. In this case, its market attractiveness is based on the increasing use of renewable resources and as a replacement for fossil fuels. As shown in Fig. 3, together with competitive advantages the product shows average results in both markets and requires further evaluation. It is also necessary to evaluate bio-oil in comparison with other alternative renewable sources and bio products. 


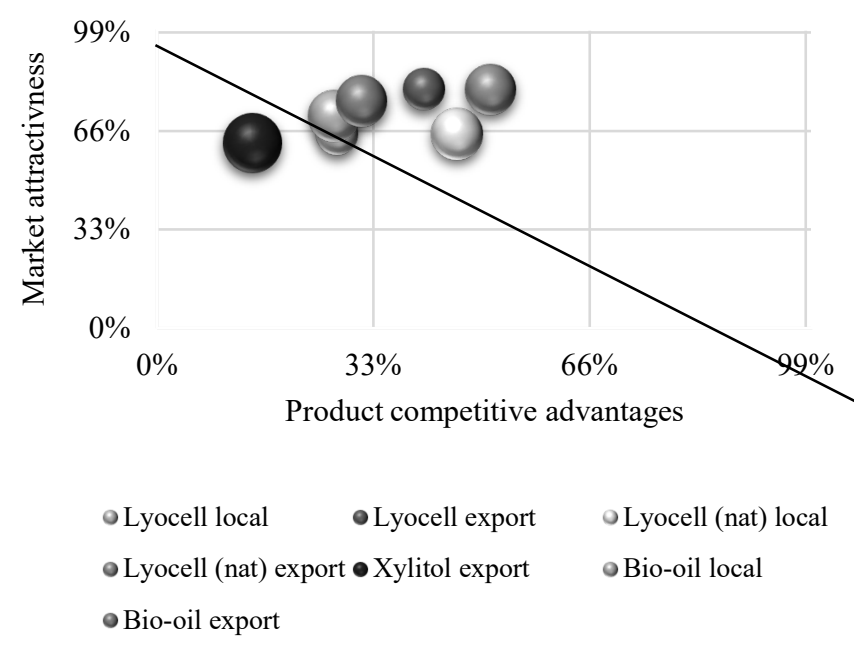

Fig. 3. Results in GE-McKinsey matrix.

Improving competitiveness for product development could be one of the recommended solutions for xylitol. Xylitol results clearly show that this is a by-product that would not bring a positive result as a primary product. It is therefore advisable to consider this as a by-product of a biorefinery [47], [48].

These results show that before building a biorefinery or any other new bio-product manufacturing facility, this type of analysis is necessary and could yield insights into overall market outlook. In the case where a cost-benefit analysis shows positive results, a market outlook analysis could be a decisive indicator in whether to invest in the product. It might also indicate the need to change some of the factors that strongly affect the results. It could even show that it is advisable to discard the product. A good feasibility study or product portfolio would help to determine which market or market segment it would be advisable to enter, which products would need further research to increase quality, and whether the technological processes used in production might be implemented in more environmentally sustainable ways.

\section{Conclusions}

The methodology used here is widely applicable and visually easily presentable and can be applied for different bio-products. The methodology can be used in the bioeconomy sector for new and innovative bio-products as well as for existing products produced from renewable biomass. The methodology is useful for decision-making based on these main factors: technology used, economic data, resource availability, planned market and product competitiveness.

The results will indicate a bio-product's market position and the decision can then be made either to enter the market as a primary product, or to improve the product or to consider a different market or market segment or even to discard the product.

If more precise evaluations are required, more variables or factors can be included. The methodology is flexible and can be expanded into different scenarios for several markets and more competitors. 


\section{ACKNOWLEDGEMENTS}

This research is funded by the Latvian Council of Science, project "Bioresources Value Model (BVM)", project No. lzp2018/1-0426.

\section{REFERENCES}

[1] Schütte G. What kind of innovation policy does the bioeconomy need? New Biotechnology 2018:40:82-86. https://doi.org/10.1016/j.nbt.2017.04.003

[2] Patermann C., \& Aguilar A. The origins of the bioeconomy in the European Union. New Biotechnology 2018:40:20 24. https://doi.org/10.1016/j.nbt.2017.04.002

[3] Van Lancker J., Wauters E., \& Van Huylenbroeck G. Managing innovation in the bioeconomy: An open innovation perspective. Biomass and Bioenergy 2016:90:60-69. https://doi.org/10.1016/j.biombioe.2016.03.017

[4] Blumberga D., et al. Why Bioeconomy is Actual for Latvia. Research Achievements in Institute of Energy Systems and Environment. Energy Procedia 2017:113:460-465. https://doi.org/10.1016/j.egypro.2017.04.039

[5] Turley D. B., et al. Chemical products from temperate forest tree species-Developing strategies for exploitation. Industrial Crops and Products 2006:24(3):238-243. https://doi.org/10.1016/j.indcrop.2006.06.016

[6] Muizniece I., Klavina K., \& Blumberga D. The Impact of Torrefaction on Coniferous Forest Residue Fuel. Energy Procedia 2016:95:319-323. https://doi.org/10.1016/j.egypro.2016.09.013

[7] Sathre R., \& Gustavsson L. Process-based analysis of added value in forest product industries. Forest Policy Economics 2009:11(1):65-75. https://doi.org/10.1016/j.forpol.2008.09.003

[8] Decuseara N. R. Using The General Electric / Mckinsey Matrix In The Process Of Selecting The Central And East European Markets. Management Strategies Journal 2013:19:59-66.

[9] Amatulli C., Caputo T., \& Guido G. Strategic Analysis through the General Electric/McKinsey Matrix: An Application to the Italian Fashion Industry. International Journal of Business Management 2011:6(5):61-75. https://doi.org/10.5539/ijbm.v6n5p61

[10] Mokaya S. O., Wakhungu B., \& Gikunda R. M. The Application of McKinsey Matrix in Determination of Route Attractiveness and Resource Allocation in Kenya Airways. International Journal of Humanities and Social Science 2012:2(3):259-268.

[11] Shen L., Zhou J., Skitmore M., \& Xia B. Application of a hybrid Entropy-McKinsey Matrix method in evaluating sustainable urbanization: A China case study. Cities 2015:42:186-194. https://doi.org/10.1016/j.cities.2014.06.006

[12] Value Based Management. Summary of the McKinsey matrix. Abstract. 2016. [Online]. [Accessed 25.03.2020]. Available: https://www.valuebasedmanagement.net/methods_ge_mckinsey.html

[13] Muška A. Uzṇēmējdarbības plānošana. (Basic business course.) Riga: KIF, 2005. (in Latvian)

[14] Borbély É. Lyocell, the new generation of regenerated cellulose. Acta Polytechnica Hungarica 2008:5(3):11-18.

[15] Lenzing Group. Leading Fiber Innovation. Lenzing Invest Present Full Year Results 2015. Lenzing: Lenzing AG, 2016.

[16] Hummel M., et al. High tenacity cellulosic fibres via ionic liquid processing. FuBio Seminar, 27 August 2013.

[17] Choudhury A. K. R. Sustainable chemical technologies for textile production. In Sustainable Fibres and Textiles 2017: 267-322. https://doi.org/10.1016/B978-0-08-102041-8.00010-X

[18] Bradley D. Markets of Pyrolysis oil. The economics of climate change mitigation options in the forest sector. Food and Agriclture Organization of the United Nations. 2015.

[19] Lehto J., et al. Fuel oil quality and combustion of fast pyrolysis bio-oils. Technical Report, June 2018. https://doi.org/10.13140/rg.2.2.15925.99042

[20] Easterly J. Assessment of Bio-oil as a Replacement for Heating Oil. Northeast Regional Biomass Program. 2002. [Online]. [Accessed 10.12.2018]. Available: http://citeseerx.ist.psu.edu/viewdoc/download?doi=10.1.1.566.6326\&re $\mathrm{p}=\mathrm{rep} 1 \&$ type $=\mathrm{pdf}$

[21] Global lyocell fiber market 2016-2020. Reasearch and markets. 2016.

[22] Pelece D. Latvijas preču eksports šḳērsgriezumā 2014. (Cross-sectional exports of Latvian goods.) (In Latvian)

[23] Guldt A. Kniep S. Successful Start-up of World's Largest Tencel Production Plant in Lenzing 2014.

[24] Russian forestry. Industrial Pulp LLC to build a mill for production of dissolving pulp in Perm Krai. Russ Timber Ind Mag 2016. [Online]. [Accessed 10.12.2018]. Available: http://www.russianforestryreview.com/news/release1156.h tml

[25] Lenzig group. Lenzing investor presentation - full year results. Lenzig Fiber Innovation 2013.

[26] Muizniece I., et al. Innovative Bioproducts from Forest Biomass. Analysis Methodology. Riga: RTU, 2016.

[27] Hou S-S., Huang W-C., Rizal F., \& Lin T-H. Co-Firing of Fast Pyrolysis Bio-Oil and Heavy Fuel Oil in a 300-kWth Furnace. Appied Sciences 2016:6(11):326. https://doi.org/10.3390/app6110326

[28] Bradley D. European Market Study for BioOil ( Pyrolysis Oil ). Climate Change Soluionst 2006:1-85. 
[29] Haikarainen J., \& Heiskanen J. Fortum invests EUR 20 million to build the world's first industrial-scale integrated biooil plant. Fortum 2012.

[30] Food and Agriculture Organization. Markets of Pyrolysis oil. The economics of climate change mitigation options in the forest sector. United Nations. 2015.

[31] Global Market Insights. Xylitol maket size by application, downstream application potential, Industry analysis, Regional outlook, production technology, Price trend, competitive market share \& forecast 2016-2023. 2016.

[32] Sarah Smith. Xylitol - A Global Market Overview. PRN 2014.

[33] Sabyr A., et al. Further development of kraft-based dissolving pulp production. 2014.

[34] Rafiqul I. S. M., \& Mimi Sakinah A. M. Processes for the production of xylitol. A review. Food Rewievs Int 2013:29:(2):127-156. https://doi.org/10.1080/87559129.2012.714434

[35] Decision Databases. Lyocell Fiber Market - Global Industry Research Report Upto 2021. Global Lyocell Fiber Market Research Report - Industry Analysis, Size, Share, Growth, Trends and Forecast 2014-2021. Report. 2016. [Online]. [Accessed 16.02.2020]. Available: https://www.decisiondatabases.com/ip/1198-lyocell-fiber-market-report

[36] Global Market Insights. Xylan market size, Industry analysis report, regional outlook, application development potential, price trends, competitive market share \& forecast, 2016-2024. 2016. [Online]. [Accessed: 16.02.2020]. Available: https:/www.yumpu.com/en/document/read/56149716/xylan-market-size-industry-share-analysis-report2024

[37] Textile exchange. Preferred fiber market report. Texas, 2016.

[38] Angel B. Product developments in manmade fibres: is cotton able to compete. Presented at the $33^{\text {rd }}$ Int. Cotton Conf., Bremen, Germany, 2016.

[39] CIRFS European Man-made fibres association. Lyocell n.d. [Online]. [Accessed: 16.02.2020]. Available: https://www.cirfs.org/man-made-fibers/Fibre-range/lyocell

[40] Textile world. Man made fibers continue to grow [Online]. [Accessed 16.02.2020.]. Available: https://www.textileworld.com/textile-world/fiber-world/2015/02/man-made-fibers-continue-to-grow/

[41] Angel B. Manmade fibres - current situation and developments aimed at sustainability Fibres. PCI Fibres 2012.

[42] European Biofuels technology platform. Bioenergy value chains 4: pyrolysis and torrefaction. 2015.

[43] ICIS Chemical Business. Lenzing's Tencel Takeover to Proceed [Online]. [Accessed 24.01.2020]. Available: https://www.icis.com/explore/resources/news/2005/02/25/654960/lenzing-s-tencel-takeover-to-proceed/

[44] Central Statistical Bureau of Latvia. Forestry - Key Indicators 2015.

[45] Dace E., Muizniece I. Modeling greenhouse gas emissions from the forestry sector - the case of Latvia. Agronomy Research 2015:13(2):464-476.

[46] Muizniece I., \& Blumberga D. Assessment of the Amount of Coniferous Wood Waste in the Baltic States. Energy Procedia 2015:72:57-63. https://doi.org/10.1016/j.egypro.2015.06.009

[47] Morales-Rodriguez R., et al. Evaluation of biorefinery configurations through a dynamic model-based platform: Integrated operation for bioethanol and xylitol co-production from lignocellulose. Renewable Energy 2016:89:135143. https://doi.org/10.1016/j.renene.2015.12.019

[48] Kamat S., et al. Coupled production of single cell oil as biodiesel feedstock, xylitol and xylanase from sugarcane bagasse in a biorefinery concept using fungi from the tropical mangrove wetlands. Bioresource Technology 2013:135:246-253. https://doi.org/10.1016/j.biortech.2012.11.059 